\title{
HISTORY OF THE MCDONALD-MERRILL-KETCHAM MEMORIAL LECTURE AND AWARD
}

The story of this award and lectureship begins with a visionary alumna of Indiana University: Dorothy M. Ketcham. Miss Ketcham received her bachelor of arts in economics in 1914 and her master of arts in sociology the following year. She joined the faculty of the University of Michigan in 1921. In 1922, she became director of social services at the University of Michigan Hospital. In this capacity, she saw the important role that medicine and law played in the lives of those whom she served. In 1928 , she established a multifaceted workshop and recreational facility for children confined to the hospital. While at the university she also wrote several books, two of which are devoted to hospital law.

Miss Ketcham's affinity for the law grew out of her family's close relationship with the legal system. Her grandfather, David McDonald, was a practicing attorney in Indianapolis, as well as a circuit judge. He was appointed to the United States District Court in 1864 where he served until his death. Dorothy's father, William A. Ketcham, was a well-known Indianapolis attorney. Prior to being admitted to the bar in 1869, he studied law with his father, John L. Ketcham and Judge David McDonald. William Ketcham was elected to the office of state attorney general in 1894 and served two terms. Miss Ketcham's interest in the health law extended beyond her scholarship.

In a trust she established for herself and four of her sisters (Miss Flora McDonald Ketcham, Dr. Jane M. Ketcham, and Misses Lilla and Lucia Ketcham), she made a remainder gift to the Indiana University Foundation to be used to assist the university in developing programs that would foster a greater understanding and better relations between the professions of law and medicine. Miss Ketcham was especially interested in furthering the careers of young medical and law students and instilling in them an appreciation for both professions.

Miss Ketcham's generous gift, named for her grandparents (Judge David McDonald, John L. Ketcham and Jane Merrill Ketcham), funds this prestigious lectureship and award for an individual who has demonstrated excellence in the fields of common interest to the two professions. It is fitting that the university honor Miss Ketcham's wishes by bringing to our campus distinguished scholars and leaders who bridge the gap between law and medicine. By inviting them to share their expertise with students, faculty and leaders of the legal and medical professions, we continue to support the ideals that Dorothy M. Ketcham espoused in her life and work. In recent years, the lecture and award have been made in collaboration with the Medical Humanities Program, a new interdisciplinary project based in the School of Liberal Arts. This addition further integrates law and medicine into the academic community and encourages each discipline to think of itself in relation to others. 


\section{MCDONALD-MERRILL-KETCHAM MEMORIAL LECTURE AND AWARD}

In conjunction with the Indiana University School of Medicine, the Law School sponsors the annual McDonald-Merrill-Ketcham Memorial Lectureship and Award for Excellence in Law and Medicine. Supported by a bequest to the two schools, this lectureship and award brings leading scholars and policy makers in the fields of law and medicine to the Indianapolis campus for the benefit of students, faculty, the bar and the medical community.

The inaugural program was held in November 1994. Award recipients and their articles are listed below. Articles based on the lectures presented were published in the Indiana Law Review until 2002, at which time the lectures started being published in the Indiana Health Law Review.

- 1994 - Tom L. Beauchamp, Professor of Philosophy and Senior Research Scholar at the Kennedy Institute at Georgetown University. The Justification of Physician-Assisted Deaths, 29 IND. L. REV. 1173 (1996).

- 1996 - Frances H. Miller, Professor of Law at Boston University School of Law and Professor of Public Health at Boston University School of Medicine. Health Care Information Technology and Informed Consent: Computers and the Doctor-Patient Relationship, 31 IND. L. REV. 1019 (1998).

- 1997 - Troyen A. Brennan, Professor of Law and Public Health at Harvard School of Public Health and Professor of Medicine at Harvard School of Medicine. Beyond Dead Reckoning: Measures of Medical Injury Burden, Malpractice Litigation, and Alernative Compensation Models From Utah and Colorado, 33 IND. L. REV. $1643(2000)$.

- 1998 - Barry S. Levy, immediate past president of the American Public Health Association and Adjunct Professor of Community Health at Tufts University School of Medicine. Twenty-First Century Challenges for Law and Public Health, 32 IND. L. REV. 1149 (1999).

- 1999 - Bernard Lo, Professor of Medicine and Director of the Program in Medical Ethics at the University of California, San Francisco. Confidentiality of Prescription Drug Information in the Era of Computers and Managed Care, 33 IND. L. REV. 937 (2000).

- 2000 - Clark C. Havighurst, William Neal Reynolds Professor at the Duke University School of Law. The Backlash Against Managed Health Care: Hard Politics Make Bad Policy, 34 IND. L. REV. 395 (2001).

- 2001 - Robert J. Levine, Professor of Medicine and Lecturer in Pharmacology at Yale University School of Medicine. International Codes of Research Ethics: Current Controversies and the Future, 35 IND. L. REV. 557 (2002). 
- 2002 - Ruth R. Faden, Philip Franklin Wagley Professor of Biomedical Ethics and Executive Director of The Phoebe R. Berman Bioethics Institute at Johns Hopkins University. Liberty, Public Health, and National Security: The Challenge of Smallpox, 1 IND. HEALTH L. REV. 1 (2004).

- $2003-$ H. Tristram Engelhardt, Jr., Professor of Philosophy at Rice University, Professor Emeritus in the Department of Medicine at Rice University, and Professor Emeritus in the Department of Community Medicine at Baylor College of Medicine. Giving, Selling, and Having Taken: Conflicting Views of Organ Transfer, 1 IND. HEALTH L. REV. 29 (2004).

- 2004 - Randall R. Bovbjerg, Research Associate, Health Policy Center, The Urban Institute, Washington, DC. Beyond Tort Reform: Fixing Real Problems, 3 IND. HEALTH L. REV. 1 (2006).

- 2005 - William M. Sage, Professor of Law at Columbia University. Pay for Performance: Will it Work in Theory?, 3 IND. HEALTH L. REV. 303 (2006).

- 2006 - James F. Blumstein, Vanderbilt University Law School, University Professor of Constitutional Law \& Policy, Director of the Health Policy Center, Vanderbilt Institute for Public Policy Studies. Of Doctors and Hospitals: Setting the Analytical Framework for Managing and Regulating the Relationship, 4 IND. HEALTH L. REV. 209 (2007). 